\title{
Being transdisciplinary theologians in and beyond apocalyptic environments
}

\begin{tabular}{|c|c|}
\hline $\begin{array}{l}\text { Author: } \\
\text { Gys M. Loubse }\end{array}$ & $r^{1}$ \\
\hline $\begin{array}{l}\text { Affiliation: } \\
{ }^{1} \text { Department } \\
\text { and Christian } \\
\text { Theology, Uni } \\
\text { Pretoria, Preto }\end{array}$ & $\begin{array}{l}\text { f Dogmatics } \\
\text { thics, Faculty of } \\
\text { ersity of } \\
\text { ria, South Africa }\end{array}$ \\
\hline $\begin{array}{l}\text { Project leade } \\
\text { Project numb }\end{array}$ & $\begin{array}{l}\text { D.P. Veldsman } \\
\text { er: } 01224719\end{array}$ \\
\hline $\begin{array}{l}\text { Description: } \\
\text { Dr Gys M. Lou } \\
\text { postdoctoral } f \\
\text { Department o } \\
\text { and Christian } \\
\text { of the researc } \\
\text { 'Religious Exp } \\
\text { evolutionary } \\
\text { directed by Pr } \\
\text { Veldsman, De } \\
\text { Dogmatics an } \\
\text { Ethics, Faculty } \\
\text { University of }\end{array}$ & $\begin{array}{l}\text { bser is a } \\
\text { ellow of the } \\
\text { f Dogmatics } \\
\text { Ethics and part } \\
\text { h project, } \\
\text { erience from an } \\
\text { erspective', } \\
\text { of. Dr Danie } \\
\text { oartment } \\
\text { Christian } \\
\text { of Theology, } \\
\text { retoria. }\end{array}$ \\
\hline $\begin{array}{l}\text { Correspondin } \\
\text { Gys Loubser, } \\
\text { gysloubser@g }\end{array}$ & $\begin{array}{l}\text { g author: } \\
\text { mail.com }\end{array}$ \\
\hline $\begin{array}{l}\text { Dates: } \\
\text { Received: } 09 \\
\text { Accepted: } 11 \\
\text { Published: } 31\end{array}$ & $\begin{array}{l}\text { May } 2016 \\
\text { Aug. } 2016 \\
\text { Oct. } 2016\end{array}$ \\
\hline $\begin{array}{l}\text { How to cite th } \\
\text { Loubser, G.M. } \\
\text { transdisciplina } \\
\text { in and beyond } \\
\text { environments } \\
\text { Teologiese Stu } \\
\text { Theological St } \\
\text { a3473. http:// } \\
\text { org/10.4102/ }\end{array}$ & $\begin{array}{l}\text { is article: } \\
\text { 2016, 'Being } \\
\text { ry theologians } \\
\text { apocalyptic } \\
\text { HTS } \\
\text { dies/ } \\
\text { udies 72(4), } \\
\text { dx.doi. } \\
\text { ts.v72i4.3473 }\end{array}$ \\
\hline $\begin{array}{l}\text { Copyright: } \\
\text { (C) 2016. The } \\
\text { Licensee: AOS } \\
\text { is licensed un } \\
\text { Creative Comr } \\
\text { Attribution Lic }\end{array}$ & $\begin{array}{l}\text { uthors. } \\
\text { S. This work } \\
\text { ler the } \\
\text { nons } \\
\text { ense. }\end{array}$ \\
\hline Read online: & \\
\hline 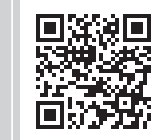 & $\begin{array}{l}\text { Scan this QR } \\
\text { code with your } \\
\text { smart phone or } \\
\text { mobile device } \\
\text { to read online. }\end{array}$ \\
\hline
\end{tabular}

This article offers a description of transdisciplinary facilitation that is suitable for theologians and ministers. The reflective aspect of transdisciplinary facilitation is illustrated through an engagement with transdisciplinary research on environmentalism and ecotheology. This article also suggests that Ernst Conradie could be appreciated, drawn on and critiqued as a transdisciplinary theologian and not a contextual theologian.

What is knowledge?

We believe many things about the world, for a great variety of different reasons. But to call a belief 'knowledge' means that it must have certain features in the way it relates to the facts. So what is it exactly that makes a belief count as knowledge? (Adam Morton [Papienau 2009])

\section{Introduction}

In this article I describe transdisciplinary facilitation by illuminating the relationship between three researchers and their descriptions of what knowledge is, how we generate knowledge and how our knowledge relates. I argue that Wentzel van Huyssteen's postfoundationalist epistemology offers an appropriate epistemology for transdisciplinary facilitation; Paul Cilliers' insights regarding complex systems illuminate the dynamics of disciplines; and Alfonso Montuori's emphasis on lived experience focuses transdisciplinary inquiry. Secondly, I focus on our environmental conversation and the way we frame Climate Change to illuminate the selfreflective characteristic of transdisciplinary facilitation.

\section{Transdisciplinary facilitation Van Huyssteen's postfoundationalist attitude}

In the early 1980s Wentzel van Huyssteen, a theologian, engaged philosophers of science and their conversations on epistemology to investigate the epistemic status of theology (Van Huyssteen 1982). ${ }^{1}$ The focus of his inquiry was to understand whether theologians generated rational knowledge even though they do not follow the methods of natural scientists (Van Huyssteen 1997). This focus prompted Van Huyssteen to develop a description of rationality that recognises the function of values and assumptions in rationality and the shaping role of context in generating knowledge (Van Huyssteen 1999, 2014:217). He argues that rationality is the epistemic skill of responsible judgement and progressive problem-solving in the pursuit of optimal understanding and intelligibility (Van Huyssteen 1999:12), and if rationality is a skill, it can be practised and improved (Van Huyssteen 1999:144). This description of rationality is drawn from a postfoundationalist epistemology that fuses epistemology and hermeneutics (Van Huyssteen 2006:22). It is an epistemology that not only appreciates a pursuit of truth and engagement with the external world, but also acknowledges the influence of assumptions and context on our descriptions of the external world.

Now, equipped with a postfoundationalist description of rationality that allows researchers from all fields to be rational, Van Huyssteen shifts his focus on the way in which theologians relate to, draw on and work with other rational agents in pursuit of optimal understanding. Cognisant of the different epistemic structures and histories of various disciplines, Van Huyssteen opts for a transversal approach to interdisciplinary research (Van Huyssteen 1998:78). This option makes it possible to shift between the different epistemic structures of disciplines, whilst protecting the integrity and contextuality of these disciplines. Although he never explicitly and systematically explains the

1.This was during the Apartheids years in South Africa, where the Dutch Reformed Church were drawing on the authority of the Bible to make decisions regarding Apartheid policy.

Note: Original Research: Volume 17 in the South African Science and Religion Forum Series, edited by Prof. Dr Cornel du Toit (UNISA) and Prof. Dr Danie Veldsman, entitled 'Creation, Consciousness and Christology: Evolutionary Perspectives', Proceedings of the 20th conference of the South African Science and Religion Forum (SASRF) of the Research Institute for Theology and Religion held at the University of South Africa, Pretoria 16-18 September 2015 
practicalities of his transversal approach, he does explain certain features of such an approach.

Van Huyssteen explains, 'it is only as individual human beings, living with other human beings in concrete situations, contexts and traditions, that we can claim some form of rationality' (2006:11). Thus, an interdisciplinary conversation occurs when, for instance, a specific theologian, with a particular worldview, engages a specific biologist, with a particular worldview, on a specific transversal issue within a transversal space (Van Huyssteen 2006:4-5). He explains that a 'transversal space' is a space between disciplines where researchers can safely cross the boundaries of their disciplines and engage shared or transversal issues. ${ }^{2}$ By crossing the boundaries of their respective disciplines into a shared space, researchers can engage each other and investigate different aspects of the transversal issue whilst protecting the integrity of their disciplines. Furthermore, it is paramount that specific researchers engage each other because researchers can help each other navigate the epistemic focus, experiential scope and heuristic structures of their respective disciplines, thereby inhibiting reductive descriptions of their disciplines and knowledge (cf. Van Huyssteen 1997:16-17).

After an interdisciplinary conversation, researchers return to their respective disciplines, carrying with them a rich description of the transversal issue (Van Huyssteen 2006a:663). Researchers themselves incorporate the insights gained into intradisciplinary research, cognisant of the history, context and identity of their discipline. The purpose of the transversal conversation is not to reach a consensus, but to explore the multiple aspects of the transversal issue, which also means that researchers do not bring back a new, closed understanding of the transversal issue to be incorporated in their discipline. Researchers have to decide which insights to incorporate and which to discard.

Van Huyssteen develops a postfoundationalist epistemology that can relate with various epistemological structures and a description of rationality that celebrates diversity in the pursuit of optimal understanding. Moreover, it is an epistemology that stimulates interdisciplinarity through embodied agents whilst being attentive to the integrity and identity of diverse disciplines. It is an epistemology that connects. ${ }^{3}$

\section{Cilliers' complex attitude}

In the last two decades complexity has become a useful and prevalent term across a wide range of disciplines. The main thrust of complexity, since its start in General Systems Theory and later in Chaos Theory, is a critique against reductionism. One of the most widely read scholars in its present form, Complexity Studies, is the engineer and philosopher Paul Cilliers. His contribution to the field has been twofold. Firstly, he describes the epistemological implications of complexity, which, I argue, connects well with Van Huyssteen's

2.Similarly, Agustin Fuentes (2013:108) identifies shared concerns, such as human nature, through his approach to transdisciplinarity. This footnote is duplicated.

3.For a more detailed discussion of Van Huyssteen's postfoundationalist approach see Loubser 2012. description of a postfoundationalist epistemology (Loubser 2013:11). ${ }^{4}$ Secondly, and important for this article, he offers a description of the dynamics of complex systems and how they interact with their environment.

Cilliers argues that living systems are better understood if understood as complex systems (dynamic), rather than complicated systems (static) (Cilliers 1998:1). When we describe a discipline ${ }^{5}$ we have to reduce it and can offer only a snapshot of that discipline. We have to decide what aspects we include and what we leave out (Woermann \& Cilliers 2012:404), which also means that every description of a discipline includes an ethical choice because researchers have to interpret the discipline and interpretation involves values and decisions (cf. Preiser 2012:22). To assist researchers in describing complex systems (here disciplines) Cilliers offers 12 characteristics of complex systems (Cilliers 2005:257). These characteristics, I argue, provide us with insight into the dynamics of disciplines and the practical aspects of transdisciplinary facilitation. Here, regarding transdisciplinary facilitation, I want to underscore that disciplines are open; they are in disequilibrium; and they have a history and change with a certain slowness.

Disciplines have porous boundaries and are in constant interaction with their environments (cf. Cilliers 1998:122). Changes in the world influence disciplines, which also means that disciplines influence each other. For instance, changes in physics (the Big Bang theory) and biology (evolutionary theory) have a profound influence on theology. Disciplinary openness makes it difficult to distinguish between disciplines and their environment (cf. Heylighen, Cilliers \& Gershenson 2007). Should we, for instance, include other religions as part of theology or are they part of theology's environment. What is important is that we decide what these boundaries will be. This openness also leads to disequilibrium (cf. Cilliers 1998:122). Disciplines are alive and change as new questions arise or established models fail to generate understanding. Transdisciplinary facilitation is therefore not a 'cut and paste' action because that which one 'cuts' is taken out of a fluctuating context. It is interacting with its environment and dealing with internal flux and as such acquires history.

The history of disciplines, together with anticipated futures, co-determines the identity of disciplines (cf. Cilliers 1998:122). How disciplines react to their environment and fluctuations are influenced by how they have responded previously and how they want to function in the future. Interestingly, disciplines are more sustainable if they allow for multiple interpretations of their histories and futures (cf. Cilliers 2007:58), which is extremely visible in South African Reformed theology where we have multiple interpretations of what a reformed identity entails. Some argue that being reformed is adhering to particular confessions made in the

4.For a more detailed discussion of Cilliers' description of complexity regarding transdisciplinarity see Loubser 2015.

5. I suggest, following Cilliers' description of postmodern society (1998:119-123) that disciplines can be described as complex systems constituted by embodied scholars. If described in this way transdisciplinary interaction is akin to the interaction between complex systems and their environment. Furthermore, I suggest that the boundaries of disciplines can be described by their epistemic focus, experiential boundaries of disciplines can
scope and heuristic structures. 
past, whilst others argue that being reformed entails adhering to certain values or 'reforming' within changing contexts. The diverse and rich variety of interpretation of a reformed identity in South Africa contributes to the sustainability of South African Reformed theology.

Although disciplines are constantly evolving and changing, Cilliers warns against an unreflective fastness in changing disciplines (cf. Cilliers 2007:54), which is very important for transdisciplinary facilitation because engaging a discipline is affecting it to a small or large extent. To maintain their identity in a fluctuating environment, certain parts of disciplines change at a slower pace than the rest (cf. Cilliers 2007:59). Disciplines that mirror their environment have no identity and will disintegrate. Changing at a slower pace allows disciplines to develop richer and more reflective capacities that assist them in dealing with surprises in their internal and external environment. ${ }^{6}$

\section{Montuori's transdisciplinary attitude}

Whilst interdisciplinarity is a fruitful approach for sharing knowledge between disciplines, transdisciplinary researchers shift the focus from disciplinary conversation to real-world problem-solving. Similar to complexity studies, researchers from diverse fields such as physics and creativity draw on this concept in engaging real-world problems, which is not surprising seeing that many transdisciplinary researchers also draw on complexity and transversality. Furthermore, like complexity, there is no definitive definition of transdisciplinarity, but a wide variety of descriptions that attempt to illuminate this approach. Although some transdisciplinary approaches are built on a specific epistemology or theory, others rather investigate scholars who cross disciplinary boundaries and seem to be disciplinary wanderers. Basarab Nicolescu, a theoretical physicist, attributes the development of transdisciplinarity to Jean Piaget who is known for his Cognitive Developmental Theory and later 'genetic epistemology' (Nicolescu 2007:35). Alfonso Montuori, whose research focuses on education and creative inquiry, suggests that Gregory Bateson and Edgar Morin are exceptional examples of transdisciplinary inquirers. ${ }^{7}$ However, 'disciplinary fragmentation' is a shared concern for transdisciplinary scholars. Some argue that disciplinary fragmentation is a legacy of industrial organisational specialisation (Montuori 2005:151) and others attribute disciplinary fragmentation to the demarcated reality of modern sciences (cf. Nicolescu 2007:37). Reality, for transdisciplinary inquirers, is not neatly demarcated to fit disciplines and therefore real-world problems can only be engaged through multiple disciplines and knowledge sources. Van Breda (2007) explains:

[O]vercoming the fundamental problem of fragmentation has to happen at the levels of theory and praxis simultaneously. We simply cannot afford any longer to look at ourselves and our relationship to the world in the dualistic terms, concepts, and

6.For a more detailed and systematic description of the phases of complex systems see Dave Snowden's Cynefin framework.

7.Interestingly, Alfonso Montuori, Basarab Nicholesu, Gregory Batson and Edgar Morin have all shown interest in engaging either theology or spirituality in their inquiries. logic of Cartesianism. We have to focus on the levels of thinking and doing at the same time. (p. 105)

To shed light on transdisciplinary facilitation I engage Alfonso Montuori. Montuori (2005:148) explains that transdisciplinary inquiry is not an additive approach. He (Montuori 2005) writes:

[T]ransdisciplinarity is an attitude towards inquiry, informed by certain epistemological presuppositions, and an effort to frame inquiry as a creative process that recognices as central the subjectivity of the inquirer and challenges the underlying organisation of knowledge. (p. 148)

This attitude, Montuori explains, is generated through lived experience and can be seen in the life and work of the French philosopher Edgar Morin (Montuori 2013:3). Living through the German invasion of France, Morin refused to equate all Germans with Nazism (Montuori 2013:2). This ethical stance against reductionism and polarisation sheds light on what he would later call 'Complex Thought' (Montuori 2013:2). It is his experience in WWII and the rise of Nazism that leads Morin (Montuori 2013) to:

[D]evelop a form of thinking - and living in the world - that is always self-reflective and self-critical, always open and creative, always eager to challenge the fundamental assumptions underlying a system of thought, and always alert for the ways in which, covertly or overtly, we create inviolate centres that cannot be questioned of challenged. (p. 4)

Morin does not only criticise reductionism, but also holism (Montuori 2013:5). Transdisciplinary inquirers should continuously move between the macro and the micro and resist reduction to either. It is a critique of 'the paradigm of simplicity', which assumes closed systems and therefore finds it appropriate to reduce (Montuori 2013:10). Behind 'simple thought' and the need for clarity lays the emotion of fear and a disregard for the sociology and psychology of knowledge (Montuori 2008:xxxix). Inquiry, for Morin, involves imagination, emotions and selfinquiry (Montuori 2008:xxxix), which is not a fall to subjectivism because if 'knowing is always performed by somebody, then that somebody can be viewed as an instrument, an instrument that has to be tuned, studied, practiced' (Montuori 2008:xxxix). So what does transdisciplinary facilitation entail?

Although there is not a systematic transdisciplinary method that can be applied, Montuori offers four characteristics of transdisciplinary facilitation that illuminates the dynamics of such an attitude to inquiry.

1. Transdisciplinary facilitation is inquiry driven (cf. Montuori 2005:154): The purpose of inquiry is to generate optimal understanding of the issue or problem in the inquirer's lived experience. To engage the issue the inquirer has to draw on multiple disciplines and knowledge sources because the issue cannot be appropriately addressed through a single discipline. In other words, transdisciplinary inquirers complexify the issue (cf. Montuori 2013a:217).

2. Transdisciplinary facilitation is meta-paradigmatic (cf. Montuori 2005:154): Disciplines have paradigmatic 
structures (constraints or boundaries) that shape the knowledge generated within the discipline, and transdisciplinary inquirers have to understand how knowledge is generated in different disciplines (Montuori 2013:6). These boundaries are important because they constitute the discipline. As such, transdisciplinary inquirers engage disciplinary assumptions which allow them to question both disciplinary assumptions and their own, and this does not replace disciplinary inquiry; rather, it enriches disciplines by offering new and indispensable insights, which cannot be generated by disciplinary inquiry alone (Montuori 2014:250). It is about connecting disciplines and an appreciation of a different way of thinking (Montuori 2013:13). As explained above, disciplines are open and they generate a structure by engaging their environment (Montuori 2013a:207).

A closed system view is extremely problematic when we begin to study living systems, because no living system can be a closed system. Every living system exists within an environment, and has a relationship with that environment. (Montuori 2013:206)

Self-organisation, the spontaneous emergence of collaboration amongst scholars in a discipline, in part, generates the structure of the discipline (cf. Montuori 2008:xxxv). Morin also stresses the importance of environment when he explains 'self-ecoorganising-knowledge' (Montuori 1998:35). The openness of disciplines and their interaction with their environment mean that the environment is in the discipline and the discipline is in the environment (Montuori 1998:35). A discipline is:

[A]n autonomous (but not isolated) system which organises itself and its environment, and is in turn radically dependent on, and co-organised by, that environment. (Montuori 1998:35)

3. Transdisciplinary facilitation involves complex thought, which is creative, contextualising and connective (cf. Montuori 2005:155): Complex thought encourages inquirers to shape and reshape their inquiry as they engage different disciplines and aspects of the issue. It is a shift from 'observed systems' to 'observing systems' because the structure of inquiry emerges from engagement with the issue in lived experience (Montuori 2013:13). In this way the uncertainty and incompleteness of living is integrated into inquiry (cf. Montuori 2013:14), and it opens the possibility of emergent creativity through interaction within a socio-historic context (cf. Montuori \& Purser 1995:89).

4. Transdisciplinary facilitation integrates the inquirer in the inquiry (Montuori 2005:157): Montuori (2005:157) explains, 'inquiry becomes an opportunity for self-contextualising, selfinquiry, and also self-creation'. Similar to Van Huyssteen's suggestion, Montuori argues that to gain understanding of the subject of inquiry, transdisciplinary inquirers need to pay attention to whom they engage and who they are (Montuori 2013a:205). It is a:

[C]all for a reflection on who we are, how we make sense of the world, and how we might find ways to embody different ways of being, thinking, relating, and acting in the world. (Montuori 2013a:214)

Recognising that who we are has an influence on how we know is extremely important, not only to transdisciplinary inquiry, but also in Van Huyssteen's description of rationality and Cilliers' distinction between information and knowledge. The diversity and plurality of knowledge is, in part, due to the diversity and plurality of knowers. Montuori, however, explains that this does not need to lead to relativism because whilst knowledge is not built on universal foundations, knowledge does have a history (cf. Montuori 1998:33).

\section{Personal epistemologies}

Our knowledge is created through contact (Montuori), constituted by constraints (Cilliers) and contextually crafted (Van Huyssteen). Most importantly, it is our knowledge and, as such, also reflects who we are. Our decisions (Cilliers), our interpretations (Van Huyssteen) and our lived experiences (Montuori) leave traces of us in our knowledge. We know as we are. This knowledge is expressed epistemologically through Van Huyssteen's description of rationality and his inquiries into our evolutionary development (Van Huyssteen 1999, 2006). Cilliers expresses it through his discussions on the ethics and dynamics involved in modelling complex systems, and Montuori does the same through describing the characteristics of transdisciplinary inquiry. These three thinkers would agree that knowledge reflects something of us, but they would also assert that our knowledge reflects reality. However, whilst these thinkers discuss macroepistemologies, I suggest that we should also pay attention to micro-epistemologies.

Barbara Hofer and Paul Pintrich, educational, developmental and cultural psychologists, discuss micro-epistemologies through what they call 'personal epistemologies' (Hofer \& Pintrich 1997:119). There are different opinions on how many stages of development are there or whether there are stages in development at all. Furthermore, some critique developmental stage theories drawing on modern epistemologies and ignoring postmodern critique of epistemology altogether. Taking that into consideration Hofer and Pintrich review a wide range of developmentalstage theories and suggest, 'there is agreement across studies as to the general trend of development' (Hofer \& Pintrich 1997:121). ${ }^{8}$ They add that this might be true only in Western culture (Hofer \& Pintrich 1997:121).

They distinguish between the 'nature of knowledge' and the 'nature of knowing' (Hofer \& Pintrich 1997:119-121). Regarding the 'nature of knowledge' they discuss 'certainty of knowledge' and 'simplicity of knowledge' (Hofer \& Pintrich 1997:119-120). Individuals differ on whether knowledge is fixed (certain) or fluid (uncertain). Those who regard knowledge as fluid are commonly open to new interpretations and theory modification (Hofer \& Pintrich 1997:120), which also links to whether the individual regards knowledge as a collection of facts (concrete) or interrelated concepts that are contingent and contextual.

Reflecting on the 'nature of knowing' Hofer and Pintrich (1997:120) distinguish between the 'source of knowledge' 8.One of the most notable scholars in the field is Jean Piaget. 
and 'justification for knowing'. Some individuals attribute their knowledge to an external source, whilst others see themselves as knowers who construct knowledge and actively generate meaning. Furthermore, the justification for knowing moves from dualistic thinking, through the acceptance of multiple opinions to what Hofer and Pintrich describe as a reasoned justification of beliefs (Hofer \& Pintrich 1997:120).

Clearly, development psychologists place high value on the description of knowledge offered by Van Huyssteen, Cilliers and Montuori. In developmental-stage theories, individuals who view knowledge as fluid, interrelated and contextual and recognise that they themselves construct meaning and justify their beliefs argumentatively have further developed personal epistemologies than those who cite static facts collected from an authoritative person or institution (Hofer \& Pintrich 1997:120). This would suggest that transdisciplinary facilitation requires highly developed personal epistemologies. Interestingly, this supports both Van Huyssteen's suggestion that rationality is a skill that can be developed and Montuori's emphasis on self-reflection in transdisciplinary inquiry. Yet, might it be that such personal epistemologies are highly valued because they are understood to be required for addressing the complexities of contemporary Western culture? It is these assumptions that have to be questioned. However, I suggest that whilst macro-epistemologies do play a vital role in the constitution of disciplines, micro-epistemologies come to the foreground in transdisciplinary facilitation.

I suggest that transdisciplinary facilitation can be described by showing the relation between Van Huyssteen, Cilliers and Montuori's work. Van Huyssteen offers an appropriate epistemology and description of rationality for transdisciplinary facilitation. Cilliers offers insight into the dynamics of disciplines and Montuori illuminates the reflective and transformative characteristics of transdisciplinary facilitation. Transdisciplinary facilitators:

- recognise the knower in generating knowledge

- engage issues disclosed through lived experience

- transversally connect and draw on numerous disciplines

- appreciate that disciplines are open, have histories and are in disequilibrium

- question disciplinary assumptions and disciplinary fragmentation and

- enrich disciplinary research.

\section{Illumination through transdisciplinary facilitation} Mike Hulme's Climate Change

One of the most prevailing issues we are faced with in our daily lives is climate change. It influences a wide range of daily activities such as our economy, our politics, our religions and our education. Climate change has developed from a preferred lifestyle to a global discussion on our survival as humans on the Earth. As can be expected of a global issue, climate change has sparked an enormous plurality of opinions, movements and ideas that range from the way we eat to the way we make sense of transcendence. As such, climate change is an extremely well-suited issue for transdisciplinary inquiry because it already involves a multitude of disciplines and a staggering array of knowledge. I suggest that Mike Hulme's Why We Disagree about Climate Change (2009) is an example of transdisciplinary inquiry and how transdisciplinary facilitation illuminates our relationship to our knowledge. He addresses climate change by reflecting on different disciplines whilst employing personal and disciplinary self-reflection.

Hulme, a professor of climate and culture, illuminates his lived experience with climate change by offering a narrative of his engagement with different aspects of climate change (Hulme 2009). He engaged climate change:

- through qualitative analysis in postdoctoral studies

- through political ideology and critiquing capitalism

- as lifestyle choice by adopting an eco-friendly lifestyle and

- policy by being part of policy discussions.

Hulme investigates different aspects of climate change and suggests that we disagree about climate change because climate change is more than a physical concept (Hulme 2009:4). Climate change alters both our physical and social worlds (Hulme 2009:4). Hulme explains that climate change has been used as the justification for commodification of the atmosphere; as inspiration for global social movements; and as validation of decisions regarding national and global security (Hulme 2009). Climate (Hulme 2009:18-27) can carry ideologies such as:

- Racism - people evolved differently because of different climates.

- Mastery over nature - we can control macro- and microclimates (air-conditioning).

- The wildness of nature - nature is fragile and needs to be protected.

- System (in)stability - stable systems are valued and we should avoid endangering system stability by pushing it to tipping points.

Climate change conversations also reveal the way we understand and use science (Hulme 2009:72). Science can be used to identify the causes of climate change; establish the value of climate; and construct the future of our world (Hulme 2009:72-73). Yet, for Hulme, it is important to realise that scientific knowledge is culturally shaped and that scientific inquiry is also driven by political and economic agendas (Hulme 2009:75). As such, scientists are found on all sides of the climate change conversation because scientific knowledge is not value-free. We disagree about science because we have different belief systems and because the values we profess seem often different to the values we act on (Hulme 2009:139). 
Our description of climate, Hulme explains, also relates to how we understand God's relation to the world (2009:148). Many religions describe the relation between humans and the Earth as one of stewardship. This approach is also expressed in many environmental movements that appreciate transcendence in human experience of nature. Extreme weather has been interpreted as either God's blessing or judgement. This type of language can be seen in secular ecological concepts such as Lovelock's Earth Mother Gaia (Hulme 2009:150). The language of sin-judgementatonement is utilised when environmentalists argue that the Earth judges our consumerism. We also commercialise this language in activities such as carbon trading and placing blame on big corporations. Many environmental movements place a high value on the spiritual over the material. They appeal to community over consumerism and egalitarian values over hierarchical values. One can even identify the evangelist characteristics in Al Gore's approach (Hulme 2009:173).

Hulme suggests that we distinguish between 'climate change' and 'Climate Change'. For Hulme, climate change is a complex problem that cannot be reduced to science, politics or economics. It is a complex issue that requires knowledge from a wide range of disciplines and knowledge sources. Climate Change, however, is not a crisis that can be solved (Hulme 2009:329). Climate Change is shaped by our belief systems (Hulme 2009:341) and the stories we tell about our relationship to our climate. Regarding 'Climate Change' we should focus on how we make sense of this relationship and how it changes as we change. To address this issue Hulme draws on one of humanities' most powerful tools - myth. He argues that myth has mystical, psychological, sociological and pedagogical functions that frame the way we make sense of our lives in the world (Hulme 2009:341). As such, Hulme argues that we have to analyse the beliefs, values and ethical commitments that drive myths of Climate Change (Hulme 2013:69). Climate Change is a mirror that exposes our individual selves and our collective societies (Hulme 2009:357). Hulme (2013) writes:

[W] need to see how we can use the idea of climate change - the asymmetric matrix of power relations, social discourses and symbolic meanings that climate change reveals - to rethink how we take forward our various political, social and economic projects over the decades to come, whatever they may be. (p. 71)

\section{Lamenting Eden}

One of the earliest myths that drive Climate Change is that the Earth has to be saved (cf. Hulme 2013:59). Part of this myth is a desire for simpler times when people lived closer to nature and cultures where much more intertwined with seasonal change. It also conveys an uncomfortable relationship with the powers that humans have acquired over nature and our own destiny.

\section{Constructing Babel}

Linked to the first myth, 'Constructing Babel' speaks to our desire for power and the pride we take in control of nature (cf. Hulme 2013:64). No matter how much we take, we will always be hungry for more - caught in an endless loop of exploiting the Earth's resources. This myth comes to the foreground in discussions regarding alternative energy sources.

\section{Celebrating jubilee}

In this myth hope is offered as an antidote to fear, and theological language of sin-repentance-justice is utilised (Hulme 2013:66-68).

\section{Presaging apocalypse}

One of the most powerful appeals to take heed of climate change conversations is apocalyptic framing in presenting climate change. Hulme suggests that apocalyptic amplification can be due to frustration and the inability to reach consensus (Hulme 2013:63). Apocalyptic framing can also reveal fear regarding the future. Interestingly, Hulme suggests that the language of complexity, thresholds and non-linearity fuels the pervasiveness of apocalyptic framing regarding climate change (Hulme 2013:63). ${ }^{9}$ Effectively, apocalyptic framing is a call to arms based on 'sound science' and not ideology (Hulme 2013:64). But is it? Hulme suggests that our apocalyptic framing of climate change may leave us disempowered (Hulme 2013:62). As such, we need to ask whether an apocalyptic frame is appropriate for Climate Change.

\section{Appropriately apocalyptical?}

In its traditional forms apocalyptic framing assumes a deterministic view of history and a search for the signs of God's will (McGinn 1994:10-12). Opponents are demonised, spectators become detached and particular agents have to nudge history to its appointed tragedy (McGinn, Collins \& Stein 2003:481) as we have seen in some modern political revolutions (Zimdars-Swartz \& Zimdars-Swartz 2003:621-622). Nordhaus and Shellenberger also argue that the stories we tell about ourselves change the world (2007:222), but suggest that people do not change the way they think when society is unstable (2007:150). Jacob Hamblin, a historian, draws a link between environmental thinking and environmental warfare (2013). The US government declassified the documents that showed how American and Russian scientists did environmental research during the Cold War in order to increase the damage done by bombs and other means of destruction. Hamblin (2013:11) argues that these scientists and their research became a part of climate change conversations, which extended war thinking into these conversations.

Fredrick Buell (2010:32) explains that the features of environmental apocalypse is a sudden rapture with the past; presentation of a revelation; narration of a world end; and dramatisation of a last judgement. Buell argues that

9.1 suggest that the approach to complexity Hulme refers to is what Morin cails 'restricted complexity' (Morin 2007). Drawing on restricts complexity, research 'restricted complexity' (Mor in 2007). Drawing on restricted complexity, researchers try to identify general laws of complex systems and then make predictions based on these laws. 'General complexity', Morin argues, is an attempt to comprehend the relations between the parts and the whole (Morin 2007:10) 
complexity studies have shown us that disequilibrium is conducive to creativity and an apocalyptic frame provides us with disequilibrium (2010:46-47). Steven M. Gardiner argues that an apocalyptic frame may only reshape, rather than undermine usual structures, and might exacerbate the problem (2010:101). However, there is scientific support that the threat of abrupt change may be sufficient motivation for change (Gardiner 2010:109). Similarly, Sahara Amsler argues that crisis is a precondition for change and can mobilise mass levels of social activity (Amsler 2010:147-148). Celia DeaneDrummond, a biologist and theologian, argues that an apocalyptic frame can be good, but suggests that there is a difference between apocalyptic narrative and apocalyptic drama (Deane-Drummond 2010:260). She argues that narrative is detached and does not give attention to individuals (Deane-Drummond 2010:263). Drama, on the other hand, allows audience members to identify with a particular character and invest in the story. DeaneDrummond (2010) writes:

The characterisation of apocalypse as drama offers, I suggest, a much greater sense of the importance of particularity and individual response compared with more fatalistic narrative approaches. (p. 270)

\section{Apocalyptic framing and transdisciplinarity}

Apocalyptic framing assumes closed or static systems that change from one state to the next or disintegrates. Complex systems are constantly changing through interaction with their environment. Small changes may have considerable influence and big changes may have little influence on the system, but complex systems are not transformed apocalyptically. Furthermore, apocalyptic framing creates dualities and easily places responsibility on leaders to prevent or establish change. In terms of micro-epistemologies, apocalyptic framing functions like less-developed personal epistemologies. Apocalyptic framing is static, a collection of facts, places responsibility on an external source and justifies through dualistic thinking. If Climate Change is a mirror and we take heed of the forming character of knowledge, apocalyptic framing reveals our inability to appreciate that our environment is in us and we are in our environment. We affect our environment and our environment affects us. We need to move beyond apocalyptic framing to move beyond an apocalyptic environment. Montuori (1998) relays Morin's concern about apocalyptic framing when he writes:

What becomes necessary is developing the capacity to develop new forms of knowledge, and alternative futures, which go beyond the gloom and doom of many ecological predictions. Global predictions must be counterbalanced with the creation of hopeful possible 'little' (local) futures as well as 'big' or global futures, and the cultivation of the capacities necessary to engage in such a creative process. (pp. 38-39)

In his article 'In die netwerk van nadenke oor die omgewing' [In the network of reflection on the environment] (2014) Ernst Conradie, an eco-theologian, suggests that we need to start 'thinking with our hands' (2014:1). By making compost, recycling, growing indigenous gardens and using electricity sparingly (Conradie 2014:2) we are confronted with questions, unearth thoughts and unlock thinking patterns that help us develop a capacity to think globally (Conradie 2014:3). This earthkeeping praxis unearths classical philosophical questions about being human, culture, history, knowledge and reality (cf. Conradie 2014:5-6). Questions are like the following: What is a human? How are we different from other species? Where do we fit in evolution? What is a 'soul'? How do we deal with our mortality? (Conradie 2014:3). Once these thoughts have been unearthed, it is a small step to reflecting on the underlying principles of our consumer society and what our education, our politics and our economy should entail (cf. Conradie 2014:3). An abundance of questions regarding the use of knowledge, how we obtain knowledge and what the role of knowledge should be in our society grows out of these reflections (Conradie 2014:4), and this raises questions regarding the subjectivity of our knowledge and what we regard as reality (cf. Conradie 2014:5). As such, Conradie suggests that:

A Christian engagement in earthkeeping is therefore not merely a matter of transformative praxis; it also provides churches with an opportunity for fundamental renewal.... This underlying logic of inquiry implies that the scope of contemporary ecotheology cannot be restricted to environmental ethics or creation theology.

In his book Christianity and Ecological Theology: Resources for further research (2006) Conradie explains that Ecological theology is 'an attempt to retrieve the ecological wisdom in Christianity', as well as 'an attempt to reinvestigate, rediscover and renew the Christian tradition in the light of the challenges posed by the environmental crisis' (Conradie 2006):

$[E]$ cological theology is not only concerned with ethics but also with Christian doctrine. It is not narrowly focused on a reinterpretation of creation theology, but calls for a review of all aspects of the Christian faith - the trinity, God as Father, creation, humanity, sin, providence, Jesus Christ, the Holy Spirit, salvation, the church, the sacraments and Christian hope. (p. 4)

Taking this into account, I suggest that Conradie's work in ecotheology is better described as transdisciplinary theology, than contextual theology. He recognises the knower in generating knowledge and engages issues disclosed and addressed through lived experience. Furthermore, he draws on numerous disciplines and appreciates that disciplines are open and have histories. Most importantly, he draws on environmental conversations to question theological assumptions and enrich theology as a discipline. Therefore, rather than a contextual theologian, we could appreciate, draw on and critique Conradie as a transdisciplinary theologian.

\section{Closing remarks}

Transdisciplinary facilitators encourage us to reconnect our knowledge and our lived experiences. They offer us ways to relate to each other and appreciate our environment. They illuminate our shared pursuit of optimal understanding and 
stimulate creative inquiry. Most importantly, they reflect on and articulate what our knowledge reveals about us and who we are, which begs the question: In an age where we are constantly connected across all four corners of the world, why do transdisciplinary facilitators emphasise 'connection' and what does it reveal about us?

\section{Acknowledgements \\ Competing interests}

The author declares that he has no financial or personal relationships which may have inappropriately influenced him in writing this article.

\section{References}

Amsler, S.S., 2010, 'Bringing hope "to crisis": Crisis thinking, ethical action and social change', in S. Skrimeshire (ed.), Future ethics: Climate change and apocalyptic imagination, pp. 147-170, Bloomsbury, New York.

Buell, F., 2010, 'A short history of environmental apocalypse', in S. Skrimeshire (ed.) Future ethics: Climate change and apocalyptic imagination, pp. 31-54, Bloomsbury, New York.

Cilliers, P., 1998, Complexity and postmodernism: Understanding complex systems, Routledge, London.

Cilliers, P., 2005, 'Complexity, deconstruction and relativism', Theory, Culture \& Society 22(5), 255-265. http://dx.doi.org/10.1177/0263276405058052

Cilliers, P., 2007, 'On the idea of a certain slowness: Stability, memory, hysterisis in complex systems', in C. Gershenson, D. Aerts \& B. Edmonds (eds.), Worldviews, science and us: Philosophy and complexity, pp. 53-64, World Scientific Publishing, Singapore.

Conradie, E.M., 2006, Christianity and ecological theology, Sun Press, Stellenbosch.

Conradie, E.M., 2014, 'In die netwerk van nadenke oor die omgewing', Verbum et Ecclesia 35(1), Art. \#813, 1-6. http://dx.doi.org/10.4102/ve.v35i1.813

Deane-Drummond, C., 2010 'Beyond humanity's end: An exploration of a dramatic versus narrative rhetoric and its ethical implications', in S. Skrimeshire (ed.), Future ethics: Climate change and apocalyptic imagination, pp. 260-277, Bloomsbury, New York.

Fuentes, A., 2013, 'Evolutionary perspectives and transdisciplinary intersections: A roadmap to generative areas of overlap in discussing human nature Theology and Science 11(2), 106-129. http://dx.doi.org/10.1080/14746700.20 13.780430

Gardiner, S.M., 2010, 'Saved by disaster? Abrupt change, political inertia and the possibility of an intergenerational arms race', in S. Skrimeshire (ed.), Future ethics: Climate change and apocalyptic imagination, pp. 101-124, Bloomsbury, New York.

Hamblin, J.D., 2013, Arming mother nature: The birth of catastrophic environmentalism, Oxford University Press, New York.

Heylighen, F., Cilliers, P. \& Gershenson, C., 2007, 'Philosophy and complexity', in J. Bogg \& R. Geyer (eds.), Complexity, science and society, pp. 117-132, Radcliffe Publishing, Oxford.

Hofer, B.K. \& Pintrich, P.R. 1997, 'The development of epistemological theories: Beliefs about knowledge and knowing and their relation to learning', Review of Educational Research 67(1), 88-140. http://dx.doi.org/10.3102/00346543067 001088

Hulme, M., 2009, Why we disagree about climate change: Understanding controversy, inaction and opportunity, Cambridge University Press, Cambridge.

Hulme, M., 2013, 'Four meanings of climate change', in S. Skrimeshire (ed.), Future ethics: Climate change and apocalyptic imagination, pp. 55-76, Bloomsbury, New York.
Loubser, G.M., 2012, 'A public theologian: A critical study of J. Wentzel van Huyssteen's Postfoundationalist facilitation of interdisciplinarity', Doctoral thesis, Stellenbosch University.

Loubser, G.M., 2013, 'A common pursuit: Paul Cilliers' and Wentzel van Huyssteen's epistemic attitudes', Nederduitse Gereformeerde Teologiese Tydskrif 54(1-2), 1-13.

Loubser, G.M., 2015, 'Becoming transdisciplinary theologians: Wentzel van Huyssteen, Paul Cilliers and Constantine Stanislavski', HTS Theological Studies 71(3), Art. \#2901, 1-9.

McGinn, B.J., 1994, Apocalypticism in the western tradition, Aldershot, Hampshire.

McGinn, B.J., Collins, J.J. \& Stein, S.J. (eds.), 2003, The continuum history of apocalypticism, Continuum, New York.

Montuori, A., 1998, 'Complexity, epistemology, and the challenge of the future', Academy of Management Proceedings 98, 31-41.

Montuori, A., 2005, 'Gregory Bateson and the promise of transdisciplinarity', Cybernetics and Human Knowing 12(1-2), pp. 147-158.

Montuori, A., 2008, 'Foreword: Transdisciplinarity', in B. Nicolescu (ed.) Transdisciplinarity: Theory and practice, pp ix-xvii, Hampton Press, Inc., Cresskill, NJ.

Montuori, A., 2013, 'Complex thought: An overview of Edgar Morin's intellectual journey', Complex thought, Metaintegral Resource Paper.

Montuori, A., 2013a, 'Complexity and transdisciplinarity: Reflections on theory and practice', World Futures 69, 200-230. http://dx.doi.org/10.1080/02604027.2013.803349

Montuori, A., 2014, 'Transdisciplinary reflections on Glăveanu's "Crisis" of the Psychology of Creativity', Creativity 1(2), 246-255.

Montuori, A. \& Purser, R.E., 1995, 'Deconstructing the lone genius myth: Toward a contextual view of creativity', Journal of Humanistic Psychology 35(3), 69-112. http://dx.doi.org/10.1177/00221678950353005

Morin, E., 2007, 'Restricted complexity, general complexity', in C. Gershenson, D. Aerts \& B. Edmonds (eds.), Worldviews, science and us: Philosophy and complexity, pp. 5-29, World Scientific Publishing, London.

Morton, A., 2009, 'Knowledge', in D. Papineau (ed.), Philosophy, pp. 72-105, Duncan Braid Publishers, London.

Nicolescu, B., 2007, 'Transdisciplinarity as a methodological framework for going beyond the science-religion debate', Transdisciplinarity in Science and Religion 2, 35-60.

Nordhaus, T. \& Shellenberger, M., 2007, Break through: From the death of environmentalism to the politics of possibility, Houghton Mifflin, Boston, MA.

Papineau, D. (ed), 2009, Philsophy, Duncan Baird Publishers, London.

Preiser, R., 2012, 'The problem of complexity: Re-thinking the role of critique', MA dissertation, Department of Philosophy, Stellenbosch University.

Van Breda, J., 2007, 'Towards a transdisciplinary hermeneutics: A way of going beyond the science/religion debate', Transdisciplinarity in Science and Religion 2, 103-156.

Van Huyssteen, J.W., 1982, Geloof en skrifgesag [Faith and the authority of scripture] (with B.J. du Toit) N.G. Kerkboekhandel, Pretoria.

Van Huyssteen, J.W., 1997, Essays in postfoundationalist theology, Eerdmans, Grand Rapids, MI.

Van Huyssteen, J.W., 1998, Duet or duel? Theology and science in a postmodern world, SCM Press, London.

Van Huyssteen, J.W., 1999, The shaping of rationality: Toward interdisciplinarity in theology and science, Eerdmans, Grand Rapids, MI.

Van Huyssteen, J.W., 2006, Alone in the World? Human uniqueness in science and theology, Eerdmans, Grand Rapids, MI.

Van Huyssteen, J.W., 2006a, 'Emergence and human uniqueness: Limiting or delimiting evolutionary explanations?', Zygon 41(3), 649-664. http://dx.doi.org/10.1111/j. 1467-9744.2005.00766.x

Van Huyssteen, J.W., 2014, 'Postfoundationlism in theology: The structure of theological solutions', Ephemerides Theologicae Lovanienses 90(2), 209-229.

Woermann, M. \& Cilliers, P., 2012, 'The ethics of complexity and the complexity of ethics', South African Journal of Philosophy 31(2), 403-419. http://dx.doi.org/10. 1080/02580136.2012.10751787

Zimdars-Swartz, S.L. \& Zimdars-Swartz, P.F., 2003, 'Apocalypticism in modern western Europe', in B.J. McGinn (ed.), Apocalypticism in the western tradition, pp. 607-627, Aldershot, Hampshire. 